\section{Violent Borders: Refugees and the Right to Move, by Reece Jones.}

Published by Verso. 2016. New York. (ISBN 978-1-78478-471-3)

\section{Martin Lemberg-Pedersen, $\mathrm{PhD}^{\star}$}

This 212-page book argues that borders immobilize international workers, preserves elites' wealth and privilege, prevents attempts to mitigate climate change, and aids in enclosing natural and oceanic commons, for the purposes of dispossession and extraction. The central premise behind this argument is a binary theorizing "movement and fixity as a conflict between the desire for freedom and the desire for control, between people who move around and people who want them to stay in place" (p.10).

Chapter 1 focus on the failures of European border politics of control and arrival in the context of the socalled "refugee crisis," including the strategy of shifting the blame for lifethreatening conditions of migrants on to "the smuggler." Chapter 2, turns to the U.S.-Mexico border illustrating the trend of militarized borders. Actors like the Joint Task Force North (JTF-N) has transferred a logic of militarization from Afghanistan and Iraq to the previously civilian contexts like crime or asylum

*) Global Refugee Studies, Institute of Culture and Global Studies, Aalborg University.

Correspondence to: lemberg@cgs.aau.dk politics (p. 42), and more than 47,000 people have lost their lives at the U.S.Mexican border (p. 45). Chapter 3 looks to border contexts, like India, Bangladesh, Israel and Australia, helpfully explaining how different states at different times invoke different (violent) border strategies. Some like India, expand massive walls, while others, like Australia, seek to preempt boat migration through a string of deals with, especially small, neighboring island states (pp. 645). Chapter 4 dives into the relationship between the global poor and borders as a strategy to maintain privilege. Through a hasty account of English serfdom and slavery, citizenship and identity documents all the way from the English Middle Ages over American slavery to the Declaration of Human Rights, Jones seeks to build an argument that the movement of the poor has been, and now again is being, being limited through violence means. Chapter 5 depicts the present enclosure of previously common resources as relatively new, tracing its emergence from the English Midlands Revolts over post-Westphalian colonialization of Africa to the enclosure of the world's oceans. Chapter 6 opens with the collapse of the Rana Plaza building that killed 1,127 factory workers. Jones ties violence inflicted on migrants to corporate globalization, tracing its rise from the 1890 s, through the 1929 crisis and onwards through the 1970 s to free trade globalization replete with WTO, NAFTA and TPP. Borders intensify environmental hazards and capture labor, he argues (p.132), feeding into the problematic narrative of developmentalism that contains labor and regulators, but not capital (p.139). Chapter 7 links together climate change 
and migration by showing how the construction and existence of borders can harm eco-systems and by arguing that violent borders contain those most impacted by environmental changes on behalf of those most responsible for extractivism (p.143). Jones concludes by arguing for open borders across the world and by encouraging movement across violent borders as an act of political resistance to "displace the nation" (p.166).

The book's notion of borders is, however, underdetermined. Its five-step taxonomy of border violence (direct infliction; threatened or actual use of power; threats of resource-grab; structural violence; environmental harm and border jurisdictions), is used to argue that borders are "inherently violent, engendering systematic violence to people and the environment" (p. 10). But this generalizes from particular functions, agents and victims, and it becomes difficult to distinguish an exceedingly widening definition of borders from (inter)national politics and the economy in general.

The book also lacks discussion of border protection. For the persecuted and traumatized, state borders can mean safety, access to health care, a future. Legal instruments like the 1951 Refugee Convention, the 1969 OAU Convention or the 1984 Cartagena Declaration allow some individuals protection. They also ensure border control, thus undermining the claim that borders always curtail freedom (p. 10). Despite the book's subtitle, little is said about refugeehood or how humanitarian borders work through intertwined registers of care and control, viewing migrants both as risk and as at risk.

Throughout the book, Jones works from a binary assumption that state borders represent fixity and mobility represents free individuals. But mobility too can be violent and exploitative. From a post/ decolonial perspective, his brief, but sweeping accounts of serfdom, slavery and European colonialism lacks attention to the trans-Atlantic slave trade to European sugar colonies in the Caribbean and Latin America and the Middle Passage's regime of forced migration for millions of enslaved people. Lacking this context, the romanticizing claim that "the oceans were one of the last bastions of free movement" in the twentieth century (p.113) inadvertently ends up emulating earlier pro-slavery narratives depicting the naval suppression of the slave trade as narrow-minded statism infringing on "cosmopolitan free trade." Lately, border studies have therefore focused more on the mobility of, within and beyond borders, but despite mentioning migrants being "funneled" (cf. p.8), Jones does not pursue the implications of this for the borders/ mobility-binary.

Jones' ambition to train our eyes on border violence is of crucial importance. The European politics of openly advocating the abandonment of boat migrants to their deaths to avoid so-called "pull factors," to hinder NGO Search and Rescue-missions in the Mediterranean, or the shooting of boat migrants illustrate that the inquiry is timely. Through statistics, anecdotes and examples, the book makes abundantly clear that this is a global trend causing thousands of deaths also in the U.S.-Mexico, Asian and Australian borderlands. Yet, its main audience is perhaps not scholars seeking nuances on border violence, but instead activists in need of an inspiring manifesto. Its underdetermined border-concept and unproblematized universalist ethics assuming open borders as a remedy means 
that it bypasses important questions about harmful mobilities, protective border functions, and the multileveled governance of borders. Still, it underscores why citizens, journalists and politicians in whose name the escalated border violence is perpetrated need to ask themselves a terrifying question: Are we approaching, or have we already passed, a tipping point after which the extermination-viaabandonment of innocent civilians is once again normalized? 